\begin{tabular}{|c|c|}
\hline Contents available at: Sri Lanka Journals Online & $\begin{array}{c}\text { Tropial } \\
\text { Aprcultural }\end{array}$ \\
\hline Journal Home Page: https://tar.sljol.info & Tropical Agricultural Research \\
\hline
\end{tabular}

\title{
Impacts of Water Scarcity Induced Adaptation Strategies on Livelihood and Household Food Security of Farming Community of Horivila- Palugaswewa and Sivalakulama Cascades of Sri Lanka
}

\author{
M. M. G. S. Dilini' ${ }^{1}$, E. R. N. Gunawardena ${ }^{2 *}$ and S. Pathmarajah ${ }^{2}$ \\ ${ }^{1}$ Postgraduate Institute of Agriculture, University of Peradeniya, Peradeniya, 20400, Sri Lanka. \\ ${ }^{2}$ Department of Agricultural Engineering, Faculty of Agriculture, University of Peradeniya, Peradeniya, 20400, Sri Lanka.
}

\section{ARTICLE INFO}

\section{Article history:}

Received: 30 July 2020

Revised version received: 31 March 2021

Accepted: 05 May 2021

Available online: 01 October 2021

\begin{tabular}{l} 
Keywords: \\
Cascade \\
Farm level and community level \\
adaptation \\
Food security \\
Livelihood \\
Water scarcity \\
\hline
\end{tabular}

\section{Citation:}

Dilini, M.M.G.S., Gunawardena, E.R.N. and Pathmarajah, S. (2021) Impacts of water scarcity induced adaptation strategies on livelihood and household food security of farming community of HorivilaPalugaswewa and Sivalakulama Cascades of Sri Lanka. Tropical Agricultural Research, 32(4):418-425

DOI: http://doi.org/10.4038/tar.v32i4.8510

Dilini, M.M.G.S.

https://orcid.org/0000-0002-2415-2047

\section{ABSTRACT}

The Dry Zone of Sri Lanka is highly vulnerable to water scarcity and hence, adaptation is considered as the key approach in reducing its impacts, especially in the agriculture sector. In this context, a study was conducted to investigate the impacts of farm level and community level adaptation strategies for water scarcity on livelihood and household food security of farmers in Horivila-Palugaswewa and Sivalakulama cascades in Anuradhapura District. Questionnaire survey with two purposive sampling with adapted and non-adapted groups was used for data collection. Use of alternative water source (agrowells), kekulama or bethma cultivation, and home gardening with vegetable and fruit cultivation were the main strategies considered to distinguish adapted group from the non-adapted group. Mann-Whitney-U test and two sample t-test were used to check statistical significance $(p<0.05)$ of desired outcomes of the strategies. Results showed that adapted group in Sivalakulama cascade has the seasonal ability of paddy cultivation and secured a marketable yield of paddy in Maha season whilst the harvest obtained from other crops in both Yala and Maha seasons were higher for the adapted group in Horivila-Palugaswewa cascade. The amount of paddy kept for household consumption in Maha season was higher for the non-adapted group for both cascades. Other than the few benefits shown above, the adaption of farm level and community level strategies for water scarcity did not comprehensively contribute to the development of livelihood or household food security of farmers in the selected study sites.

\footnotetext{
*Corresponding author: ernimalg@gmail.com
} 


\section{INTRODUCTION}

Sri Lanka is highly vulnerable to climate change (MMDE, 2016). Its impacts are visible with the increases in the frequency and intensity of disasters such as droughts, floods, landslides, variability and unpredictability of rainfall patterns, (Government of Sri Lanka, 2010). Instead to its' inherent dry condition, the dry zone of Sri Lanka is increasingly becoming highly vulnerable to prolonged droughts (Ministry of Environment Sri Lanka, 2011).

Adaptation is the key strategy available for facing the impacts of climate change (MMDE, 2016). Around 28\% of the country's population depends on livelihoods related to agriculture, which are highly dependent on climatic conditions. Impacts on agriculture will place not only the livelihood of farmers, but food security of the entire population at risk. Measures to deal with the impacts of climate change have the objective of reducing the vulnerability of human and natural systems (FAO, 2012). Vicious circle of poverty is impacting on smaller scale farming communities as low productivity and income matters to them (Todaro, 1997). Agro-based livelihood, rain-fed agriculture, fragmented and smaller area of land, increased population and high economic growth, institutional and policy deficiencies, insurance scheme failures, and high food price fluctuations have identified as major reasons to highlight the importance of adaptation strategies to South Asian agriculture (Aryal et al., 2019).

Adapting to the potential effects of climate change, such as water scarcity, is not a mere process and requires individual as well as collective actions (Scheraga et al., 2003). Though there are several international, regional, national as well as community level initiatives to cope under these circumstances, small scale farming sector in South Asian region is still not showing any improvements (Ojha, 2012). The situation is not uncommon to Sri Lanka, especially with regard to the dry zone farming system which is characterized by two major cultivation seasons viz Yala (Minor cultivation season) and Maha (Major cultivation season).

It is to be noted that farmers in Sri Lanka have a long history of water scarcity adaptation (Athula and Rodrigo, 2014). Sri Lanka's dry zone farming systems are not purely rain-fed as there are extensive distributions of village tanks (reservoirs). Yet, it is apparent that impacts of water scarcity and socio-economic transformations may have gone beyond the carrying capacity of this village tank-based systems. Consequently, village tank communities also become vulnerable to climate change (Athula and Scarborough, 2011; Dishani and Silva, 2016). There have been a number of climate change related projects introduced by the Government of Sri Lanka to reduce vulnerabilities and improve the resilience of these village tank-based farming communities (MMDE, 2017; Ministry of Agriculture, 2018). However, the information on the effectiveness of adaptation strategies in improving the livelihood and household food security of farmers is not available. Therefore, this study was conducted in two village tank cascade systems in the dry zone to find out the impacts of major water scarcity adaptation strategies on livelihood of farmers and their food security.

\section{METHODOLOGY}

\section{Study Site}

As illustrates in the Figure 1, the study was conducted at Horivila-Palugaswewa cascade and Sivalakulama cascade in the Anuradhapura District. Both are located within the Malwathu Oya river basin. The Horivila-Palugaswewa cascade has an extent of about 2312 ha and consists of 14 village tanks, whereas Sivalakulama cascade has an area of about 2137 ha with 20 village tanks. The mean annual rainfall of this area ranges from 1500 - $1850 \mathrm{~mm}$ and annual mean temperature vary from $27.3-36^{\circ} \mathrm{C}$ (Wijeratne and Piyadasa, 2014). The main soil type is Reddish Brown Earth (Panabokke, 2000). Chena/Other Field Crops are recognized as the prominent practice for Yala season whilst paddy cultivation is dominant during the Maha season.

Farmers of the Horivila-Palugaswewa cascade are engaged in paddy cultivation under minor irrigation in both Yala and Maha while Sivalakulama farmers engage extensively in Maha season paddy farming under minor irrigation. Furthermore, Horivila-Palugaswewa cascade farmers were involved in rainfed cultivation during both seasons while Sivalakulama farmers practiced rainfed paddy cultivation only during Maha season. Scarcity of water during the Yala season may be a reason for not cultivating paddy in Sivalakulama cascade.

\section{Questionnaire Survey}

A questionnaire survey was conducted during the period of October 2019 to February 2020. Purposive sampling technique was used for the survey with 200 farmers. Sample selection was 


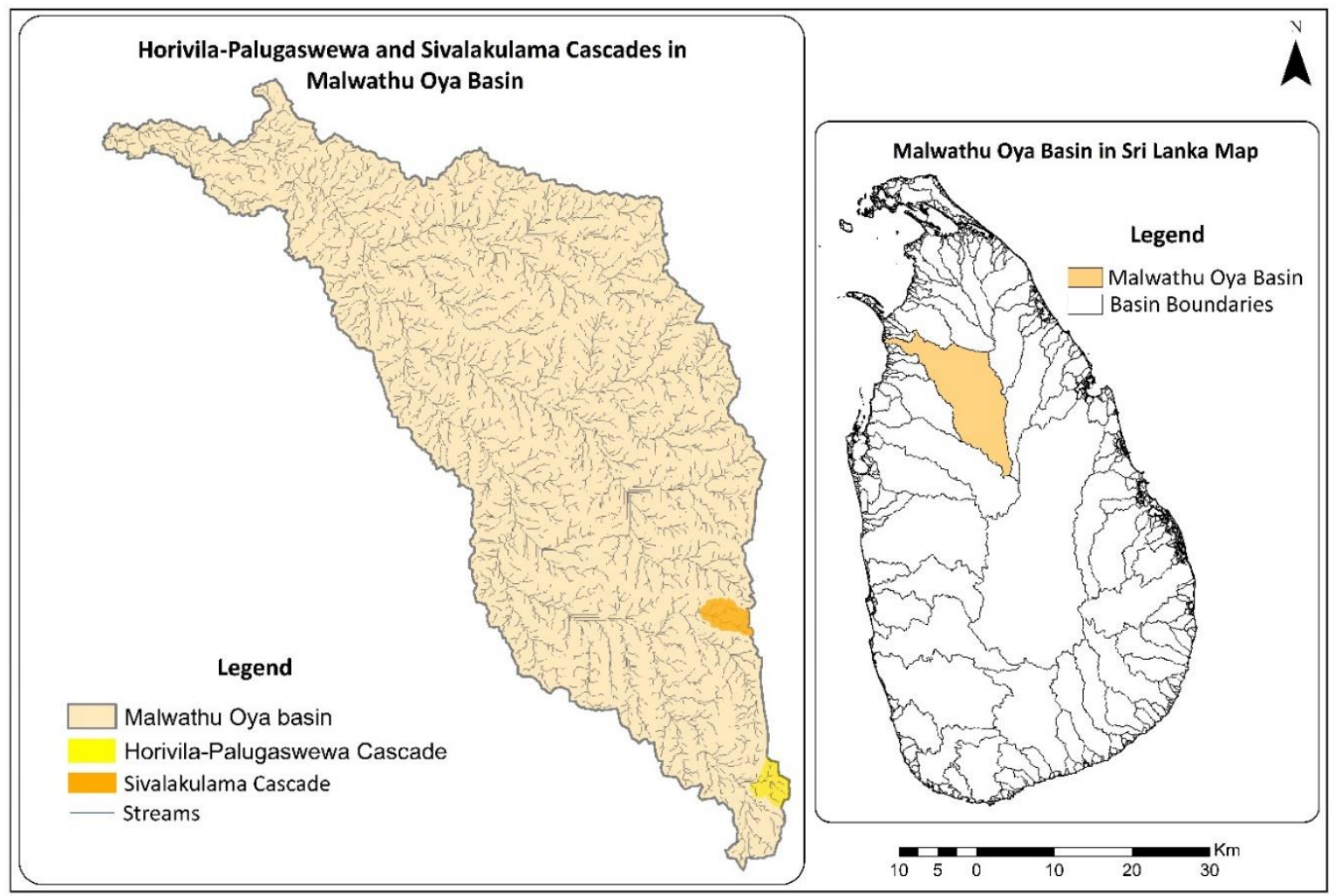

\section{Figure 1: The study site}

carried out to represent 50 farmers who did and did not adapt water scarcity adaptation strategies in each cascade. Use of alternative water source (agro-wells), kekulama or bethma cultivation, and home gardening with vegetable and fruit cultivation were considered as three main water scarcity adaptation strategies to differentiate the adapted group from the non-adapted group. The support of Agricultural Research Production Assistants and Agricultural Instructors were also used to verify the farmers in each group.

\section{Statistical analysis}

\section{Mann-Whitney-U test}

The effectiveness of implementing water scarcity adaptation strategies on farmers' livelihood and food security was compared between adapted and non-adapted groups for two different crops, i.e. other crops and paddy. Since it was practically difficult to obtain numerical data for some of the parameters for various combinations of other crops that the farmers cultivate, ordinal data was obtained. The ordinal data obtained through the questionnaire consists of, a) seasonal ability of cultivation in a year, b) extent of land cultivated for other crops, c) personal monetary expenditure for other crops, d) harvest obtained from other crops, e) amount kept for household consumption from other crops, f) marketable yield from other crops, and g) average agricultural income from other crops. Mann-Whitney-U test was used to test whether the ordinal variables obtained differ between adapted and non-adapted groups at $p<0.05$ level. Responses were recorded separately for adapted and non-adapted groups and as well as for the Yala and Maha cultivation seasons. Tests were conducted separately for the data obtained from Horivila-Palugaswewa cascade and Sivalakulama cascade using SPSS 16.0 software.

\section{Two Sample t-tests}

In contrast to the combinations of other crops, it was possible to obtain numerical data for paddy cultivation. Therefore, two samples t-test was used for statistical analysis to determine the differences of means of adapted group and non-adapted group at $p<0.05$ significant level. The numerical data obtained from two groups for both Yala and Maha cultivation season in each cascade includes, a) cultivated extent of paddy lands, b) personal monetary expenditure for paddy cultivation, c) harvest obtained from paddy cultivation, d) amount kept for household consumption from paddy cultivation, e) marketable yield from paddy, and f) average agricultural income from paddy. Two samples t-test for both adapted and not adapted groups for each cascade were conducted using the SPSS. 


\section{RESULTS AND DISCUSSION}

\section{Water Availability}

The scarcity of surface water in Sivalakulama cascade is reflected by the use of alternative water sources by the farmers. Agricultural Instructors have reported that number of agro-wells has exceeded 400 according to the latest count. There are 45 tube wells as well. In contrast, there are only 89 agro-wells in Horivila-Palugaswewa cascade.

Bethma is a practice where only a portion of land close to the tank is cultivated with available water to adapt during water scarcity situations. According to the Agrarian Officers, there are many issues among farmers in agreeing to this practice in the current context. Paddy with $31 / 2$ month duration (BG 300, BG 358, and BG 359) is the most common varieties cultivated with bethma practice in the study site. There are hardly any records of bethma practice in Sivalakulama cascade. Majority of farmers in Sivalakulama cascade did not cultivate paddy during Yala season. Instead, they cultivate other crops during Yala season.

Farmers may not go for any adaptation mechanism if they have adequate of water for their cultivation. As Table 1 shows, that out of 100 , a total of 72 and 86 farmers from Horivila-Palugaswewa and Sivalakulama cascade, respectively have responded that they have water shortage for cultivation. It is noteworthy to mention that, 44 responses of water shortage have come from farmers who were in adaptation groups in both cascades.

Presence of water shortage is not uniform throughout the year. Table 2 and 3 indicate those who encountered water shortage for paddy and other crops during Yala and Maha seasons. As expected, water shortage is comparatively low during the Maha season.

\section{Effects of Water scarcity Adaptation Strategies on Other Crop Cultivation}

The results of various parameters used to determine the impact of water scarcity adaptation strategies on other crop cultivation in HorivilaPalugaswewa and Sivalakulama cascades in Yala and Maha seasons are given in Table 4. It is apparent that the ability of cultivation during Yala season differs among adapted and non-adapted groups in Sivalakulama cascade. As per crosstabulations, $84 \%$ of adapted farmers cultivate other crops whilst $16 \%$ of adapted farmers were able to cultivate both paddy and other crops during
Yala season. In contrast, all non-adapted farmers cultivated only other crops during Yala season. In fact, farmers who adapted water scarcity strategies have benefitted by securing the ability to cultivate during water scarcity scenarios in the water-short Yala season. Comparatively, a higher number of agro-wells (i.e. all members of adapted group own agro-wells) within the adapted group may have been a reason for that observation. As per crosstabulations, there is $8 \%$ of adapted farmers who were able to cultivate both paddy and other crops during Yala season while all non-adapted farmers cultivate only other crops during Yala season. The harvest obtained from other crops in both Yala and Maha seasons by the adapted group is significantly higher (94\% in Yala and 56\% in Maha) than the non-adapted group (66\% Yala and 6\% in Maha) in Horivila-Palugaswewa cascade. Tendency towards home gardening among the adapted group of farmers is considered as a possible reason for this finding.

The field observations indicate that there is no difference between the types of other crops cultivated by adapted and non-adapted farmers. There were no mono cropping among the sampling groups in the Horivila-Palugaswewa cascade and farmers cultivate multiple varieties of other crops in their uplands. Though the Sivalakulama cascade farmers have given priority to cultivate maize during Yala season, the practice was similar among adapted and non-adapted groups. Water melon (Citrulluslanatus), pumpkin (Cucurbita), mung bean (Vigna radiata), sesame (Sesamum indicum), and capsicum (Capsicum annuum) are the popular crops cultivate in Yala season in both study sites.

\section{Effects of Water scarcity Adaptation Strategies on Paddy Cultivation}

Since rice is the staple food in Sri Lanka, paddy cultivation is the most important agricultural practice in the country. Though the purchase of rice from groceries or super markets is the common practice for urban dwellers, it is unusual to rural paddy farming communities. Therefore, rural farming communities cultivate paddy and keep it for their own consumption irrespective of financial benefits. Farmers of these two study sites cultivate paddy under minor irrigation water or rainfed. Horivila-Palugaswewa cascade farmers involve in paddy cultivation using water from both sources during both seasons. Though the Sivalakulama farmers extensively practice paddy farming under minor irrigation and to certain extent as rainfed in Maha season, there is no apparent Yala season paddy cultivation except few cases. 
Table 1: Water shortage issue for cultivation among adapted and non-adapted groups for HorivilaPalugaswewa and Sivalakulama cascades

\begin{tabular}{|c|c|c|c|c|}
\hline \multirow[b]{2}{*}{ Cascade } & \multicolumn{4}{|c|}{ Water shortage issue for cultivation } \\
\hline & Group & Yes & No & $\begin{array}{c}\text { No. of } \\
\text { response }\end{array}$ \\
\hline \multirow[t]{3}{*}{ Horivila-Palugaswewa } & Adapted & 44 & 6 & 50 \\
\hline & Non-adapted & 28 & 22 & 50 \\
\hline & Total & 72 & 28 & 100 \\
\hline \multirow[t]{3}{*}{ Sivalakulama } & Adapted & 44 & 6 & 50 \\
\hline & Non-adapted & 42 & 8 & 50 \\
\hline & Total & 86 & 14 & 100 \\
\hline
\end{tabular}

Table 2: Water shortage issue for cultivation during Yala season among adapted and non-adapted groups for Horivila-Palugaswewa and Sivalakulama cascades

\begin{tabular}{lcccc}
\hline \multirow{2}{*}{ Cascade } & \multicolumn{2}{c}{ Water shortage issue for cultivation (Yala) } \\
\cline { 2 - 5 } & Group & $\begin{array}{c}\text { For other } \\
\text { crops }\end{array}$ & $\begin{array}{c}\text { For both } \\
\text { crops }\end{array}$ & $\begin{array}{c}\text { No. of } \\
\text { response }\end{array}$ \\
\hline Horivila-Palugaswewa & Adapted & 34 & 10 & 44 \\
& Non-adapted & 19 & 9 & 28 \\
& Total & 53 & 19 & 72 \\
Sivalakulama & Adapted & 2 & 42 & 44 \\
& Non-adapted & 2 & 40 & 42 \\
\hline
\end{tabular}

Table 3: Water shortage issue for cultivation during Maha season among adapted and non-adapted groups for Horivila-Palugaswewa and Sivalakulama cascades

\begin{tabular}{|c|c|c|c|c|c|}
\hline \multirow[b]{2}{*}{ Cascade } & \multicolumn{4}{|c|}{ Water shortage issue for cultivation (Maha) } & \multirow[b]{2}{*}{$\begin{array}{c}\text { No. of } \\
\text { response }\end{array}$} \\
\hline & Group & $\begin{array}{c}\text { For } \\
\text { paddy }\end{array}$ & $\begin{array}{c}\text { For other } \\
\text { crops }\end{array}$ & $\begin{array}{l}\text { For both } \\
\text { crops }\end{array}$ & \\
\hline \multirow[t]{3}{*}{ Horivila-Palugaswewa } & Adapted & 0 & 2 & 1 & 3 \\
\hline & Non-adapted & 0 & 5 & 1 & 6 \\
\hline & Total & 0 & 2 & 7 & 9 \\
\hline \multirow[t]{3}{*}{ Sivalakulama } & Adapted & 8 & 0 & 4 & 12 \\
\hline & Non-adapted & 12 & 2 & 6 & 20 \\
\hline & Total & 20 & 2 & 10 & 32 \\
\hline
\end{tabular}


Table 4. Mann-Whitney-U test statistics on seasonal ability of cultivation in a year and other livelihood indicators for adapted and non-adapted groups in Horivila-Palugaswewa and Sivalakulama cascades in Yala and Maha seasons

\begin{tabular}{|c|c|c|c|c|}
\hline \multirow{3}{*}{ Indicator } & \multicolumn{2}{|c|}{$\begin{array}{l}\text { Horivila-Palugaswewa } \\
\text { cascade }\end{array}$} & \multicolumn{2}{|c|}{$\begin{array}{l}\text { Sivalakulama } \\
\text { cascade }\end{array}$} \\
\hline & \multicolumn{4}{|c|}{ Asymp. Sig. (2-tailed)a } \\
\hline & Yala season & Maha season & Yala season & Maha season \\
\hline Seasonal ability of cultivation in a year & 0.082 & 0.165 & $0.003^{*}$ & 0.645 \\
\hline Extent of land cultivated for other crops & 0.402 & 0.402 & 0.402 & 0.402 \\
\hline $\begin{array}{l}\text { Personal monetary expenditure for } \\
\text { other crops }\end{array}$ & 0.171 & .171 & 1.000 & 0.560 \\
\hline Harvest obtained from other crops & $0.028^{*}$ & $0.028^{*}$ & 0.310 & 0.648 \\
\hline $\begin{array}{l}\text { Amount kept for household } \\
\text { consumption from other crops }\end{array}$ & 0.648 & 1.000 & 0.560 & 0.648 \\
\hline Marketable yield from other crops & 0.560 & 0.648 & 0.317 & 0.317 \\
\hline $\begin{array}{l}\text { Average agricultural income from other } \\
\text { crops }\end{array}$ & 0.297 & 0.142 & 0.142 & 0.142 \\
\hline
\end{tabular}

a. Grouping variable: adapted and non-adapted groups.

*Statistically significant at $p<0.05$

Table 5: Two Samples t-test statistics on paddy cultivation for adapted and non-adapted groups in Horivila-Palugaswewa and Sivalakulama cascades in Yala and Maha seasons

\begin{tabular}{|c|c|c|c|c|}
\hline \multirow{3}{*}{ Indicator } & \multicolumn{2}{|c|}{$\begin{array}{l}\text { Horivila-Palugaswewa } \\
\text { cascade }\end{array}$} & \multicolumn{2}{|c|}{$\begin{array}{l}\text { Sivalakulama } \\
\text { cascade }\end{array}$} \\
\hline & \multicolumn{4}{|c|}{ Asymp. Sig. (2-tailed)a } \\
\hline & Yala season & Maha season & Yala season & Maha season \\
\hline Extent of land cultivated for paddy & 0.646 & 0.633 & 0.193 & 0.273 \\
\hline $\begin{array}{l}\text { Personal monetary expenditure for } \\
\text { paddy }\end{array}$ & 0.547 & 0.818 & 0.539 & 0.331 \\
\hline Harvest obtained from paddy & 0.682 & 0.729 & 0.234 & 0.055 \\
\hline $\begin{array}{l}\text { Amount kept for household } \\
\text { consumption from paddy }\end{array}$ & 0.381 & $0.001^{*}$ & 0.234 & $0.042^{*}$ \\
\hline Marketable yield from paddy & 0.750 & 0.213 & - & $0.008^{*}$ \\
\hline Average agricultural income from paddy & 0.807 & 0.801 & - & 0.587 \\
\hline
\end{tabular}

a. Grouping variable: adapted and non-adapted groups.

*Statistically significant at $p<0.05$

Note: As there was no marketable yield from paddy during Yala season for Sivalakulama cascade, no agricultural income was recorded in the table.

As shown in Table 5, there is a significant difference between adapted and non-adapted groups with regard to the amount of paddy kept for household consumption in Maha season in Horivila-Palugaswewa cascade. The mean value of paddy kept for household consumption of the nonadapted group (81.10 bushels/household) is higher than the adapted group $(70.00$ bushels/household). Similar results were obtained for the amount of paddy kept for household consumption in Maha season in Sivalakulama cascade as well. The mean value of the amount kept for household consumption by non-adapted group (79.41 bushel/household) is higher than the adapted group (71.94 bushel/household). The non-adapted farmers do not practice bethma cultivation during water scarcity periods and therefore, they have to totally rely on the harvest 
from the Maha season. Therefore, to ensure food security they tend to store more paddy for household consumption.

There is also a significant difference between adapted and non-adapted groups in terms of marketable yield from paddy in Maha season at Sivalakulama cascade as marketable yield from paddy in Maha season showed a high mean value for adapted group (173.67 bushels/households) compared with the non-adapted group (139.02 bushels/households). Only limited number of farmers in this cascade cultivate paddy in Yala season manly for their own consumption due to water shortage. As a result, there is no marketable yield and income from paddy in the Yala season.

\section{CONCLUSIONS}

The farmers who adapted water scarcity adaptation strategies were able to secure the seasonal ability of cultivation in Yala season and have a marketable yield of paddy in Maha season in Sivalakulama cascade, whereas the harvest obtained from other crops in both seasons was

\section{REFERENCES}

Aryal, J. P., Sapkota, T. B., Khurana, R., KhatriChhetri, A., Rahut, D. B., and Jat, M. L. (2019). Climate change and agriculture in South Asia: adaptation options in smallholder production systems. Journal of Springer; Environment Development and Sustainability. https:// doi.org/10.1007/s10668-019-00414-4

Athula, S., and Rodrigo, C. (2014). Agriculture Adaptation Practices in South Asia:Case of Sri Lanka[online]. [Accessed on 22.05.2020]. Available at https://www.researchgate.net/ publication/264417804_Agriculture_Adaptatio n_Practices_in_South_Asia_Case_of_Sri_Lanka

Athula, S., and Scarborough, H. (2011). Coping with Climatic Variability by Rain-fed Farmers in Dry Zone, Sri Lanka: Towards Understanding Adaptation to Climate Change [online]. [Accessed on 22.05.2020]. Available at https://www.researchgate.net/publication/25 4385392_Coping_with_Climatic_Variability_by_ Rain-fed_Farmers_in_Dry_Zone_Sri_Lanka_ Towards_Understanding_Adaptation_to_Climat e_Change higher for the adapted group in HorivilaPalugaswewa cascade. The amount of paddy kept for household consumption in Maha season was significantly higher for the non-adapted group for both cascades. This may be due to the uncertainty of paddy cultivation in the Yala season due to dry weather conditions. This is also considered as an adaptation strategy by the farming community to ensure household food security for their families throughout the year. The marketable yield of paddy in the adapted group is found to be significantly higher in Sivalakulama cascade, as this is the only season for them to cultivate paddy. Irrespective of few benefits shown above, the adaption of water scarcity strategies did not comprehensively contribute to the development of livelihood or household food security of farmers in the Dry Zone.

\section{ACKNOWLEDGMENTS}

This work was carried out with the aid of a grant from the International Development Research Centre, Ottawa, Canada. Their financial support is greatly appreciated.

Dishani, P. T. N., and Silva, C. S. D. (2016). Present Status of Agricultural Production in the Dry Zone of Sri Lanka and the Possible Adaptation Measures- A Case Study in Rajangana, Anuradhapura District [online]. [Accessed on 27.05.2020]. Available at https://www. researchgate.net/publication/312171885_PRE SENT_STATUS_OF_AGRCULTURAL_PRODUCTI ON_IN_THE_DRY_ZONE_OF_SRI_LANKA_AND_T HE_POSSIBLE_ADATATION_MESURES-A_CASE _STUDY_IN_RAJAGANA-ANURADHAPURA_ DISTRICT_Enter_title

FAO. (2012). Climate change and food security: Climate change adaptation and mitigation in agriculture [online]. [Accessed on 24.02.2020]. Available at http://www.fao.org/elearning/ Course/FCC/en/pdf/learnernotes0856.pdf

GEF/SGP Sri Lanka. (2016). Coping with climate change and Variability: Lessons from Sri Lankan Communities [online]. [Accessed on 22.05.2020]. Available at https://reliefweb. int/sites/reliefweb.int/files/resources/Coping $\% 20$ with\%20Climate $\% 20$ Change $\% 20$ and $\% 20$ Variability.pdf

Government of Sri Lanka. (2010). The National Climate Change Adaptation Strategy for Sri Lanka 2011 to 2016 [online]. [Accessed on 
21.10.2018]. Available at: https://www. climatechange.lk/adaptation/Files/Strategy_B ooklet-

Ministry of Agriculture. (2018). Climate-Smart Irrigated Agriculture Project in Sri Lanka. Ministry of Agriculture, Colombo, Sri Lanka.

Ministry of Environment Sri Lanka. (2011). Climate Change Vulnerability Data Book [online]. [Accessed on 22.05.2020]. Available athttps://final_climate_change_vulnerability_d atabook.pdf

MMDE. (2016). National Adaptation Plan for Climate Change Impacts in Sri Lanka: 20162025. Climate Change Secretariat, Ministry of Mahaweli Development and Environment. Colombo, Sri Lanka.

MMDE. (2017). Project Document on strengthening the resilience of smallholder farmers in the dry zone to climate variability and extreme events through an integrated approach to water management. Ministry of Mahaweli Development and Environment, Colombo, Sri Lanka.

Ojha, H. (2012). Is agricultural system adapting to climate change in South Asia? [online].
[Accessed on 21.05.2020]. Available at https://ccafs.cgiar.org/fr/blog/agriculturalsystems-adapting-climate-change-southasia\#.XuMkH9UzbDc

Scheraga, J. D., Ebi, K. L., Furlow, J., and Moreno, A. R. (2003). From science to policy: developing responses to climate change [online]. [Accessed on 22.05.2020]. Available at https:// www. semanticscholar.org/paper/From-science-topolicy\%3A-developing-responses-to-ScheragaEbi/2ffbea08a95284b9bbd34b89f2d151e742 dd28ee

Wijeratne, V. P. I. S. and Piyadasa, R. U. K. (2014). Identification of Spatial Distribution and Issues related to Groundwater Quality in Palugaswewa DS Division in Anuradhapura District. Symposium Proceedings of The Water Professionals' Day, Water Resources Research in Sri Lanka, Cap-Net Lanka, Postgraduate Institute of Agriculture and Geo-Informatics Society of Sri Lanka in collaboration with United Nations Development Programme. pp. 102.

Todaro, P. M. (1997). Economic Development in the Third World, 4th Ed. McGraw Hill Ins. USA. 